\title{
Changes in soil microbial activity and physicochemical properties in agricultural soils in Eastern Spain
}

\author{
Cambios en la actividad microbiana del suelo y en las propiedades físicoquimicas de suelos \\ agrícolas del Sudeste de España \\ Alteraçôes na atividade microbiológica do solo e propriedades físicoquimicas em solos \\ agricolas do Sudeste de Espanha
}

\section{AUTHORS}

\section{Morugán- \\ Coronado A. ${ }^{@, 1,2}$ \\ amorugan@umh.es}

\section{García-Orenes F. ${ }^{2}$}

Cerdà $A$

@ Corresponding Author

${ }^{1}$ SEDER (Soil Erosion and Degradation Research Group), Departament de Geografia, Universitat de València, Blasco Ibáñez, 28. 46010 València, Spain.

${ }^{2} \mathrm{GEA}$ (Environmental Soil Science Group). Agrochemistry and environmental, University Miguel Hernández. 03202-Elche, Alicante, Spain.
Received: 11.05.2015 | Revised: 08.10.2015 | Accepted: 09.10.2015

\section{ABSTRACT}

Agricultural land management greatly affects soil properties. Microbial soil communities are the most sensitive and rapid indicators of perturbations in land use and soil enzyme activities are sensitive biological indicators of the effects of soil management practices. Citrus orchards frequently have degraded soils and this paper evaluates how land management in citrus orchards can improve soil quality. A field experiment was performed in an orchard of orange trees (Citrus Sinensis) in the Alcoleja Experimental Station (Eastern Spain) with clay-loam agricultural soils to assess the long-term effects of herbicides with inorganic fertilizers $(\mathrm{H})$, intensive ploughing and inorganic fertilizers $(\mathrm{P})$ and organic farming $(\mathrm{O})$ on the soil microbial properties, and to study the relationship between them. Nine soil samples were taken from each agricultural management plot. In all the samples physicochemical parameters, basal soil respiration, soil microbial biomass carbon, microbial indexes (BSR/C, $\mathrm{Cmic} / \mathrm{C}$ and BSR/Cmic) and enzymatic activities (urease, dehydrogenase, $ß$-glucosidase and acid phosphatase) were determined. The results showed significant differences between the different agricultural management practices for the microbial properties and soil microbial indexes, since these were strongly associated with the soil organic matter content. Unlike herbicide use and intensive ploughing - management practices that both showed similar microbial soil properties - the organic management practices contributed to an increase in the soil biology quality, aggregate stability and organic matter content.

\section{RESUMEN}

El manejo agricola afecta a las propiedades del suelo asi como a las comunidades microbianas, ya que son altamente sensibles frente a cambios en el uso del suelo y pueden utilizarse como in dicadores de calidad frente a las perturbaciones en ese uso como, por ejemplo, las actividades enzimáticas. El cultivo del naranjo puede degradar los suelos, por lo que este estudio tiene como objetivo evaluar cómo el manejo agrícola en un cultivo de naranjo puede mejorar la calidad del suelo y las propiedades microbiológicas del mismo. El experimento se llevó a cabo en una finca de naranjos (Citrus Sinensis) situada en Alcoleja (comarca de la Costera, Valencia, España), donde se instalaron tres parcelas con tres manejos agricolas distintos. La primera parcela $(H)$ se encuentra fertilizada inorgánicamente y se aplican herbicidas; la segunda parcela $(P)$ está sometida a un labrado continuo donde además se fertiliza inorgánicamente; $y$, por último, en la parcela $(O)$ se aplica agricultura de producción ecológica. De cada parcela de estudio se tomaron nueve muestras de suelo, en las que se determinaron: parámetros fisicoquimicos, respiración edáfica basal, carbono de la biomasa microbiana, indices microbianos (BSR/C, Cmic/C y BSR/Cmic) y actividades enzimáticas (ureasa, deshidrogenasa, $\beta$-glucosidasa y fosfatasa ácida). Los resultados mostraron diferencias significativas entre los distintos manejos agrícolas para los indices microbianos y las propiedades microbiológicas, ya que éstos están altamente relacionados con el contenido de materia orgánica del suelo. Por otro lado, las parcelas H y P obtuvieron resultados similares para dichas propiedades, mientras que la parcela con agricultura ecológica obtuvo los valores más altos para el contenido en materia orgánica, agregación y actividad biológica del suelo. 


\section{RESUMO}

As práticas de gestão agrícola afetam intensamente as propriedades do solo. As comunidades microbianas, são os indicadores mais rápidos e sensiveis face a perturbaçôes no uso do solo enquanto as atividades enzimáticas funcionam como excelentes indicadores biológicos da qualidade do solo face aos efeitos dessas práticas de gestão. A cultura de citrinos é frequentemente responsável pela degradação dos solos, pelo que este estudo tem como objetivo avaliar como as práticas de gestão agricola num pomar de citrinos podem contribuir para melhorar a qualidade do solo e as propriedades microbiológicas do mesmo. O ensaio foi realizado num pomar de laranjeiras (Citrus Sinensis) situado na Estação Experimental de Alcoleja (Valencia, Espanha), em solos agricolas argilo-limosos, onde de instalaram três talhões submetidos a três práticas agricolas distintas. O primeiro talhão $(H)$ recebeu fertilização mineral e foram aplicados herbicidas; o segundo talhão (P) foi submetido a uma lavoura contínua e a fertilização mineral; e, por ültimo, o talhão (O) foi submetido a agricultura de produção orgânica. De cada talhão foram colbidas nove amostras de solo, para determinação de: parámetros fisicoquímicos, respiração basal, carbono da biomassa microbiana, indices microbianos (BSR/C, Cmic/C y BSR/Cmic) e atividades enzimáticas (urease, deshidrogenase, $\beta$-glucosidase e fosfatase ácida). Os resultados revelaram diferenças significativas entre os diferentes tipos de práticas agricolas para os indices microbianos e propriedades microbiológicas, já que estes estão altamente relacionados com o teor de materia orgánica do solo. Por otro lado, os talhóes $H$ e P apresentaram resultados similares para as ditas propriedades, enquanto que o talhão com agricultura de produção orgânica apresentou os valores mais altos para o conteúdo em matéria orgánica, agregação e atividade biológica do solo.

\section{Introduction}

Land management in agricultural areas has an important influence on microbial soil properties (García-Orenes et al. 2013). Different agricultural management practices influence soil microorganism and soil microbial processes through changes in the quantity and quality of organic residues in the soil, their spatial distribution, changes in nutrient input and physical changes. Unsuitable land management can lead to a loss of soil fertility and a reduction in the abundance and diversity of soil microorganisms, for example intensive arable farming causes a progressive decline of soil organic matter (Caravaca et al. 2002) affecting physical, chemical biochemical and microbiological properties. The excessive use of herbicides can drastically modify the function and structure of soil microbial communities and alter the terrestrial ecosystem, with important changes in soil fertility and quality (Pampulha and Oliviera 2006). However, some organic amendments can promote the activities of soil microbial communities and increase biodiversity (García-Orenes et al. 2010). The application of soil conservation management systems - keeping cover crops on the soil surface and minimizing soil tillage - is becoming usual because of the increasing interest in sustainable agriculture (Roldán et al. 2003). The application of different types of cover on the soil surface can decrease soil temperature changes, keeping the soil cool and moist during the dry season and promoting microbial activity and crop development.

The Mediterranean belt is suffering from an intense degradation of its soils due to the millennia old land use (Zornoza et al. 2007), the use and abuse of the soil system due to non-sustainable management practices, land abandonment in the 1950s and 60s, and now as a consequence of the intensification of agricultural management (Cerdà et al. 2010). This area is characterised by the depletion of SOM after millennia of ploughing and burning. In the 20th century, the arrival of herbicides, chemical fertilizers, fungicides and insecticides 
(biocides in general) drastically modified the function and structure of microbial communities, altering the terrestrial ecosystems, which has important implications for soil quality (Sofo et al. 2012; Imfeld and Vuilleumier 2012). Soil biota also contributes substantially to the resistance and resilience of agroecosystems to abiotic disturbance and stress. The microbial members of soil communities are the most sensitive and rapid indicators of perturbations and land use changes. In this sense, a quantitative description of microbial community structure and diversity has aroused great interest as a potential tool for soil quality evaluation (Zelles 1999; Zornoza et al. 2009).

Soil organic matter (SOM) improves a soil's chemical and physical properties, promoting biological activity and maintaining environmental quality, and this is why organic fertilisers, such as manure, promote the activities of soil microbial communities (Morugán-Coronado et al. 2011; Balota et al. 2013; Macci et al. 2013). Plants and microorganisms are key players within the soil ecosystem and are responsible for many important soil cycling processes, such as $\mathrm{C}$ mobilization and $\mathrm{N}$ mineralization. On the other hand, land use influences soil microbial processes and structure of microbial communities (Blagodatskaya et al. 2011; GarcíaOrenes et al. 2013).

Organic agriculture management promotes the maintenance of SOM levels for soil fertility, providing plant nutrients through the microbial decomposition of organic materials, and the control of pests, disease, and weeds with crop rotation, natural control agents and pest-resistant plant varieties (Lampkin et al. 2011). Also these soils have a significantly higher microbial biomass, larger fractions of mineralizable $\mathrm{C}$ and $\mathrm{N}$, and greater microbial $\mathrm{C}$ (Reganold et al. 2010). Also this management has a positive effect on soil structure with the improvement of stability of aggregates.

This is why we are applying an integrated approach by measuring the microbiological characteristics of the soil, the enzymatic activities and the soil physiochemical properties with different agricultural managements, including organic farming. This will allow an understanding of the impact of land management on the soil system.

We hypothesised that organic farming practices applied in field experiments, could mean a significant improvement in soil physical, chemical and biological properties.

The main goal of this study is to determine the impact of land management changes (from ploughing to herbicides and to organic farming) on soil microbial and biochemical properties in citrus orchards in Eastern Spain.

\section{Material and Methods}

\subsection{Study site}

This research was conducted at the Alcoleja Experimental Station located in L'Alcúdia de Crespins municipality, $60 \mathrm{Km}$ from the coast in the Eastern Iberian Peninsula, in the southwest of the Valencia province (UTM: 709191X, 4316356Y; Zone 30), at 156 m.a.s.I. The climate is typically Mediterranean with a mean annual precipitation of $500 \mathrm{~mm}$ and a mean annual temperature of $16^{\circ} \mathrm{C}$. The soil is a Xerorthent (Soil Survey Staff 2010). The texture of soil is clay-loam, consisting of $20 \%$ clay, $40 \%$ silt, and $40 \%$ sand.

\subsection{Experimental design}

The three plots studied located on one farm at the Alcoleja Experimental Station have been planted with citrus (Citrus Sinensis) for the last 30 years. The planting pattern is $7 \times 4 \mathrm{~m}$, the usual pattern for citrus in this agricultural area. All the three orchards of this study have been flood-irrigated with fresh water from the Sants River, which is a spring of the Macizo 
del Caroig aquifer. The spring supplies the discharge for the irrigation and is $2 \mathrm{~km}$ from the experimental station. No pollution, no sources of $\mathrm{OM}$ and no wastewater are mixed with the high quality water coming from the spring. The three areas of this study are flooded every 20 days in summer $\left(700 \mathrm{~m}^{3} \mathrm{ha}^{-1}\right.$ per irrigation) from April to October and no irrigation takes place in winter. The irrigation schedule is based on the farmer's experience. Three different agricultural managements were established in the experimental station: i) $(\mathrm{H})$ herbicides with inorganic fertilizers applied before irrigation (Glyphosate ( $N$-(phosphonomethyl)glycine) 4 times per year; NPK $15 \%, 1 \mathrm{Mg} \mathrm{ha}^{-1}$ per year) established 30 years ago, ii) (P) ploughing 5 days after the irrigation and inorganic fertilizers applied before the flooding (NPK 15\%,1 $\mathrm{Mg} \mathrm{ha}^{-1}$ per year) established 30 years ago and iii) $(O)$ organic farming established 8 years ago (chipped pruned branches and weeds, manure from sheep and goats, $20 \mathrm{Mg}^{-1}: 0.07 \% \mathrm{~N}$, $0.03 \% \mathrm{P}_{2} \mathrm{O}_{5}$, and $0.09 \% \mathrm{~K}_{2} \mathrm{O}$ applied once per year, in winter, after the harvest of the oranges, usually in January).

\subsection{Soil sampling}

In July 2013, nine soil samples from individual trees were collected in a randomised design from each agricultural management area: herbicide with inorganic fertilizers $(H)$, ploughed with inorganic fertilizers $(P)$ and organic with manure, weeds and chipped pruned branches (O). The soil samples were taken from $0-5 \mathrm{~cm}$ and were collected from three neighbouring farms, with the individual sampling points less than 10 meters apart. Field-moist soil samples were sieved at $2 \mathrm{~mm}$ and stored at environmental temperatures to conduct the physicochemical analysis. Soil sample aliquots (a portion of the total amount of a field soil sample) were sieved between $0.25-4 \mathrm{~mm}$ to determine the percentage of stable aggregates. An aliquot of every soil sample was kept cool $\left(4^{\circ} \mathrm{C}\right)$ to carry out the microbiological analysis.

Vegetation cover (Veg) was determined as the percentage of soil covered by plants (Cerdà et al.
2007). The plant recolonization was calculated at the 9 sampling points for each treatment by means of a $50 \times 50 \mathrm{~cm}$ square frame, and vegetation cover was measured at 100 points (each $5 \times 5 \mathrm{~cm}$ ) by a pin.

2.4. Soil physicochemical, microbiological and biochemical analyses

Soil $\mathrm{pH}$ and electrical conductivity $(\mathrm{EC})$ were measured with a 1:5 (w/v) aqueous solution. The basal soil respiration (BSR) was measured using a multiple sensor respirometer (Micro-Oxymax, Columbus, OH, USA). Soil organic matter (SOM) was determined by Walkley and Black (1934), available $\mathrm{Na}, \mathrm{K}, \mathrm{Mg}$ and $\mathrm{Ca}$ were extracted with $1 \mathrm{~N}$ ammonium acetate (Knudsen et al. 1982) measured by atomic absorption and emission spectrophotometry. The reason for the inclusion of $\mathrm{Na}$ in the study is because the research is focused mainly on potential soil degradation and $\mathrm{Na}$ is related to sodicity processes, which lead to the loss of soil structure due to clay dispersion. Cation exchange capacity (CEC) was measured by the method described by Roig et al. (1980). Microbial biomass carbon ( $\mathrm{Cmic}$ ) was extracted using the chloroform fumigation and extraction procedure (Vance et al. 1987). Soluble carbon (Csol) from the soil solution was extracted through potassium dichromate digestion, following the Jenkinson and Powlsow method (1976). The carbon mineralization coefficient (BSR/C), Cmic/C ratio and metabolic quotient (BSR/Cmic) were determined. These indexes are able to evaluate microbial activity under different land management practices. Aggregate stability (AS) was measured using the method of Roldán et al. (1994); this method examines the proportion of aggregates that remain stable after a soil sample (sieved between 0.25-4 mm) is subjected to an artificial rainfall of known energy $\left(270 \mathrm{~J} \mathrm{~m}^{-2}\right)$. Total nitrogen (Nk) was determined by the Kjeldahl method (Bremmer and Mulvaney 1982). Available phosphorus (AP) was determined by the Burriel-Hernando method (Díez 1982). Water holding capacity (WHC) was assayed by the method of Forster (1995). Calcium carbonate equivalent (Carb) and calcium carbonate content of limestone $\left(\mathrm{CaCO}_{3}\right)$ 
were measured by Porta et al. (1986). Urease activity (EC 3.5.1.5) was assayed according to the method of Tabatabai (1994), using urea as the substrate. Dehydrogenase activity (DHA) was determined according to García et al. (1997). Phosphatase (PHP) (EC 3.1.3.1) and $\beta$-glucosidase ( $\beta$-Glc) (EC 3.2.1.21) activities were determined using $p$-nitrophenyl phosphate disodium (PNPP, 0.115M) and $p$-nitrophenyl- $\beta$ D-glucopyranoside (PNG, 0.05M) as substrates, respectively. The assay is based on the release and detection of $p$-nitrophenol (PNP) according to Tabatabai (1994).

\subsection{Statistical analyses}

The fitting of the data to a normal distribution for all soil properties was checked with the Kolmogorov-Smirnov test at $p<0.05$. To compare the effect of different agricultural managements, an ANOVA test was done. We tested for the significance between treatments for each soil to observe changes over treatments. The separation of means was carried out according to the average post-hoc Tukey test $p<0.05$, assuming equal variance. Pearson's correlation coefficients $(R)$ were calculated to quantify the linear relationship between parameters. All soil properties from all samples were subjected to principal component analysis (PCA) to elucidate major variation patterns in terms of the three treatments and to establish relationships between variables and treatments of the study. To perform correlation-based PCA $(p \leq 0.05)$, the data was normalized in order to have the same $(=1)$ variance for the samples along all species axes. Correlation criterion $>0.4$ in different components. Sampling adequacy of individual and set variables by KMO $(>0.5)$ and Bartlett's test of sphericity $(<0.05)$ were done, WHC was removed from PCA analysis because this variable obtained communality value $<0.5$. The selection of main components was regulated by the latent root criterion (eigenvalues $>1.0$ ) and the classification of soil properties by component was performed by varimax rotation. Alexakis (2011) concluded that principal component analysis proves a successful tool for the interpretation of results. All statistical analysis was performed with the SPSS program (Statistical Program for the Social Sciences 18.0).

\section{Results}

\subsection{Physicochemical parameters}

Table 1 shows the vegetation cover, texture, $\mathrm{pH}$, $\mathrm{EC}$, Carb, $\mathrm{WHC}, \mathrm{CaCO}_{3}, \mathrm{CEC}$, macronutrients $(\mathrm{Na}, \mathrm{Ca}$ and $\mathrm{Mg}$ ). The maximum vegetation cover was observed in the $\mathrm{O}$ plot $(42.2 \%)$ with less cover in the other agricultural managements ( $H: 1.2 \%$ and $\mathrm{P}: 1.1 \%)$. The main weeds species observed with organic farming management practices were Brachypodium retusum (pers.) Beauv. and Cistus albidus L. (Table 1). The ploughed soil $(P)$ had the highest clay content, and the highest values of $\mathrm{WHC}$ and $\mathrm{CaCO}_{3}$ in comparison to the herbicide $(\mathrm{H})$ and organic farming (O) land managements, $\mathrm{CaCO}_{3}$ was statistically higher for both, $\mathrm{P}$ and $\mathrm{O}$ treatments (Table 1). The $\mathrm{pH}$ level in the plots ranged from 7.9 in $\mathrm{O}$ plot to 8.3 in P plot. In the O plot, soils showed a statistically significantly higher content of salts (EC) and a slight decrease in $\mathrm{pH}$ was observed compared with the other agricultural managements studied. Although the $\mathrm{pH}$ and $\mathrm{EC}$ were significantly different between treatments, if we observe the $\mathrm{pH}$ and $\mathrm{EC}$ classifications (Soil Survey Staff 2010) pH was moderately alkaline (between 7.9 and 8.4) and EC was not saline $(<2 \mathrm{dS} / \mathrm{m})$ (Table 1). The lowest value of CEC was found in $\mathrm{H}$ plot and the highest value of CEC was found in O plot, CEC was statistically low for both, $\mathrm{H}$ and $\mathrm{P}$ treatments (Table 1 ).

The $\mathrm{H}$ plot did not show differences in the fertility parameters (Table 1 and Figure 1 ). The percentage of sand in this plot $(\mathrm{H})$ was higher than for the other agricultural managements (Table 1). 
Table 1. Main soil characteristics and vegetation cover of different treatments (Herbicides with inorganic fertilizers $(H)$, intensive ploughing and inorganic fertilizers $(P)$ and organic farming $(O)$ ). Values are mean \pm standard deviation

\begin{tabular}{|c|c|c|c|}
\hline & \multirow[b]{2}{*}{$\mathrm{O}^{*}$} & \\
\hline & & $\mathrm{H}$ & $\mathrm{P}$ \\
\hline $\operatorname{Veg}(\%)$ & $42.2 \pm 8.9^{a}$ & $1.3 \pm 0.6^{b}$ & $1.1 \pm 0.6^{b}$ \\
\hline Texture $(\% \text { clay, silt, sand })^{\star \star}$ & $19^{\mathrm{ab}}, 40^{\mathrm{a}}, 39^{\mathrm{a}}$ & $17^{\mathrm{a}}, 34^{\mathrm{b}}, 48^{\mathrm{b}}$ & $23^{b}, 43^{a}, 34^{c}$ \\
\hline $\mathrm{pH}($ extract $1: 5, \mathrm{w} / \mathrm{v})$ & $7.9 \pm 0.2^{\mathrm{a}}$ & $8.2 \pm 0.2^{b}$ & $8.3 \pm 0.1^{\mathrm{b}}$ \\
\hline $\mathrm{EC}\left(1: 5, \mu \mathrm{S} \mathrm{cm} \mathrm{cm}^{-1}\right)$ & $244 \pm 28^{a}$ & $201 \pm 44^{b}$ & $175 \pm 14^{b}$ \\
\hline Carb (\%) & $48 \pm 6^{a}$ & $33 \pm 4^{b}$ & $46 \pm 4^{a}$ \\
\hline WHC (\%) & $50 \pm 9^{\mathrm{ab}}$ & $44 \pm 3^{\mathrm{a}}$ & $52 \pm 2^{b}$ \\
\hline $\mathrm{CaCO}_{3}(\% \mathrm{o})$ & $147 \pm 16^{\mathrm{a}}$ & $104 \pm 19^{b}$ & $157.8 \pm 14^{\mathrm{a}}$ \\
\hline $\operatorname{CEC}\left(\mathrm{cmol} \mathrm{kg}^{-1}\right)$ & $11.8 \pm 2.8^{\mathrm{a}}$ & $6.7 \pm 0.8^{b}$ & $8.10 \pm 2.0^{\mathrm{b}}$ \\
\hline Macronutrients $\left(\mathrm{g} \mathrm{kg}^{-1}\right) \mathrm{Na}, \mathrm{Ca}, \mathrm{Mg}$ & $0.99^{a}, 3.27^{a}, 0.52^{a}$ & $1.11^{\mathrm{a}}, 2.70^{\mathrm{b}}, 0.41^{\mathrm{b}}$ & $1.10^{\mathrm{a}}, 2.90^{\mathrm{c}}, 0.55^{\mathrm{a}}$ \\
\hline \multicolumn{4}{|c|}{$\begin{array}{l}\mathrm{n}=27 .{ }^{*} 0-5 \mathrm{~cm} \text { depth. }{ }^{* *} \text { Sand: } 2-0.02 \mathrm{~mm} \text {, silt: } 0.02-0.002 \mathrm{~mm} \text {, clay: }<0.002 \mathrm{~mm} \text {. } \\
\text { EC: Electrical conductivity; WHC: Water holding capacity; Carb: Calcium carbonate equivalent; } \mathrm{CaCO}_{3} \text { : Calcium carbonate content of } \\
\text { limestone; } C E C \text { : Cation exchange capacity; Veg: Vegetation cover. } \\
(\% \circ) \text { parts per mil' symbol. } \\
\text { A one-way ANOVA }(\mathrm{P}<0.05) \text { were used to compare differences between managements. } \\
\text { Different letters indicate significant differences }(\mathrm{P}<0.05) \text { between soil management for each treatment according to one-way ANOVA. }\end{array}$} \\
\hline
\end{tabular}

Figure 1 shows the content of the main nutrients parameters studied ( $N, P$ and $K$ ) in the three different agricultural management soils. This information shows that the soil under 0 management had a higher content of these important elements for soil fertility. The $\mathrm{H}$ plot was the one that had the lowest values in SOM, N, P and $\mathrm{K}$ content. Furthermore, the $\mathrm{O}$ plot showed the highest content in SOM reaching almost $8 \%$ against the low content of the other agricultural managements studied, which reached $2 \%$, SOM was statistically low for both, $\mathrm{H}$ and $\mathrm{P}$ treatments (Figure 1). Agricultural management with $\mathrm{O}$ increased the $\mathrm{N}$ content five times compared to the other management plots. Available $\mathrm{P}$ and available $\mathrm{K}$ obtained were at their maximum in the $\mathrm{O}$ plot. For available $\mathrm{P}, \mathrm{H}$ and $\mathrm{P}$ treatments showed the lowest values while for available $\mathrm{K}$ only, $\mathrm{P}$ treatment showed the lowest value.

Figure 1 also shows the percent aggregate stability at each plot. The $O$ management obtained the highest level of AS which seems to be related with the organic matter content.
3.2. Microbial biomass carbon, basal respiration, microbial indexes and enzymatic characterization of the soil

The microbial biomass carbon is considered the most active and living part of $\mathrm{OM}$ and is composed of microorganisms that participate in different processes in the soil. Soils under O management had highest levels of Cmic, Csol and BSR. The statistical analysis for Cmic shows the lowest value in $\mathrm{P}$ treatment. For $\mathrm{Csol}$ and BSR only, $\mathrm{H}$ treatment showed the lowest value (Table 2 ). To evaluate microbial activity under different land management systems we analysed the carbon mineralization quotient (BSR/C), Cmic/C ratio and metabolic quotient (BSR/Cmic). Very low values were obtained for BSR/C and BSR/Cmic. However there are statistical differences between treatments, $\mathrm{Cmic} / \mathrm{C}$ soils under $\mathrm{O}$ treatment showed the lowest values (Table 2).

Enzymatic activities (dehydrogenase, urease, phosphatase and $\beta$-glucosidase) were measured in the three types of agricultural management (Figure 2A, B, C and D). Significant differences were found between the organic management and the other management systems for all enzymatic activities studied. The DHA enzyme 

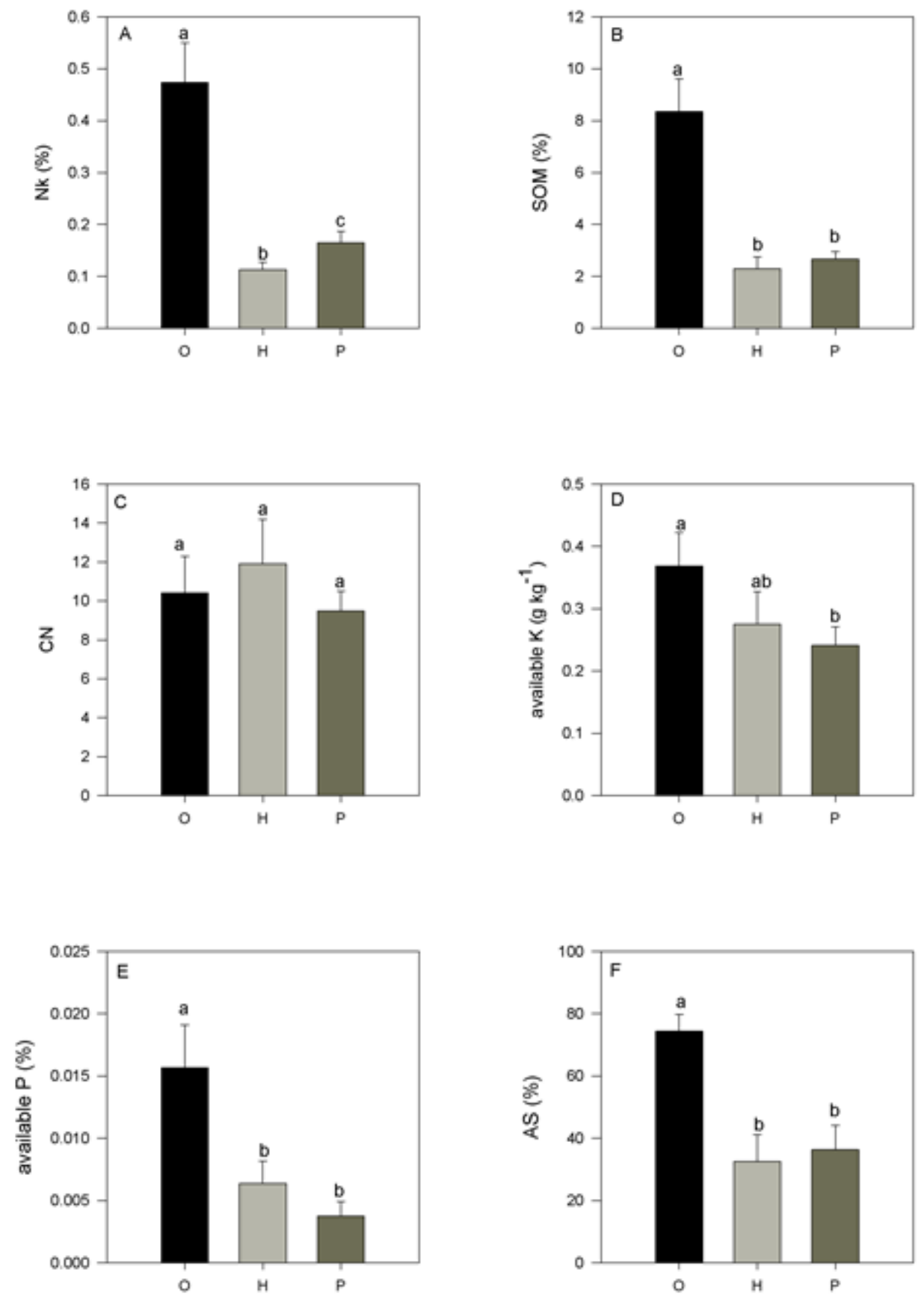

Figure I. Mean values ( \pm standard deviation) of $(\mathbf{A})$ total nitrogen, $(\mathbf{B})$ soil organic matter $(\mathrm{SOM}),(\mathbf{C}) \mathrm{C} / \mathrm{N}$ relation, (D) available potassium, $(\mathbf{E})$ available phosphorus, $(\mathbf{F})$ aggregate stability (AS) in soil. Different letters indicate significant differences $(P<0.05)$ between soil management - from black (organic farming-O), light gray (herbicide-H) to dark gray (ploughing-P) - for each treatment according to one-way ANOVA.

activity (Figure $2 \mathrm{~B}$ ) in the soil reflects the total oxidative activity of the microbes, and its concentration was high in $\mathrm{O}$ plot indicating that the activity of the microbial community increases with agriculturally sustainable management.
We have not recovered data about the productivity of harvest in the different agricultural managements because the objective of this study was evaluating effects on soil properties not in crop productivity. 
Table 2. Main biochemical soil properties of different treatments (Herbicides with inorganic fertilizers $(H)$, intensive ploughing and inorganic fertilizers $(P)$ and organic farming $(0)$ ).

\section{Values are mean \pm standard deviation}

\begin{tabular}{|c|c|c|c|}
\hline & \multirow[b]{2}{*}{$\mathrm{O}^{*}$} & \\
\hline & & $\mathrm{H}$ & $P$ \\
\hline $\mathrm{Cmic}\left(\mathrm{mg} \mathrm{C} \mathrm{kg}^{-1}\right)$ & $2293.4 \pm 366.2^{\text {a }}$ & $2087.3 \pm 362.3 \mathrm{ab}$ & $1923.1 \pm 148.7^{b}$ \\
\hline Csol (mg C kg-1) & $263.8 \pm 47.7^{\text {a }}$ & $61.2 \pm 6.7^{\mathrm{b}}$ & $128.0 \pm 10.2^{c}$ \\
\hline $\mathrm{BSR}\left(\mu \mathrm{g} \mathrm{C}-\mathrm{CO}_{2} \mathrm{~g}^{-1}\right.$ soil $\left.\mathrm{h}^{-1}\right)$ & $1.1 \pm 0.3^{a}$ & $0.5 \pm 0.2^{b}$ & $0.8 \pm 0.3^{a}$ \\
\hline \multicolumn{4}{|l|}{ Mineralization quotient } \\
\hline $\mathrm{BSR} / \mathrm{C}\left(\mu \mathrm{g} \mathrm{C}-\mathrm{CO}_{2} \mathrm{~g}^{-1} \mathrm{Csol} \mathrm{h} \mathrm{h}^{-1}\right)$ & $2.2 \cdot 10^{-2} \pm 4.5 \cdot 10^{-3} \mathrm{a}$ & $3.7 \cdot 10^{-2} \pm 2.1 \cdot 10^{-2} \mathrm{ab}$ & $5.4 \cdot 10^{-2} \pm 2.2 \cdot 10^{-2} \mathrm{~b}$ \\
\hline $\mathrm{Cmic} / \mathrm{C}$ (mgC biomass $\mathrm{mg}$ total organic $\mathrm{C}^{-1}$ ) & $47.9 \pm 8.0^{a}$ & $163.0 \pm 49.4^{b}$ & $125.3 \pm 15.9^{c}$ \\
\hline \multicolumn{4}{|l|}{ Metabolic quotient } \\
\hline $\mathrm{BSR} / \mathrm{Cmic}\left(\mu \mathrm{g} \mathrm{C}-\mathrm{CO}_{2} \mathrm{~g}^{-1} \mathrm{Cmic} \mathrm{h}^{-1}\right)$ & $4.8 \cdot 10^{-4} \pm 1.3 \cdot 10^{-4} \mathrm{a}$ & $2.2 \cdot 10^{-4} \pm 6.8 \cdot 10^{-5 b}$ & $4.3 \cdot 10^{-4} \pm 1.6 \cdot 10^{-4} \mathrm{a}$ \\
\hline
\end{tabular}

$\mathrm{n}=27 .{ }^{*}$ 0-5 cm depth. Cmic: Microbial biomass carbon; Csol: Soluble carbon; BSR: Basal soil respiration.

A one-way ANOVA $(P<0.05)$ were used to compare differences between managements.

Different letters indicate significant differences $(P<0.05)$ between soil management for each treatment according to one-way ANOVA.
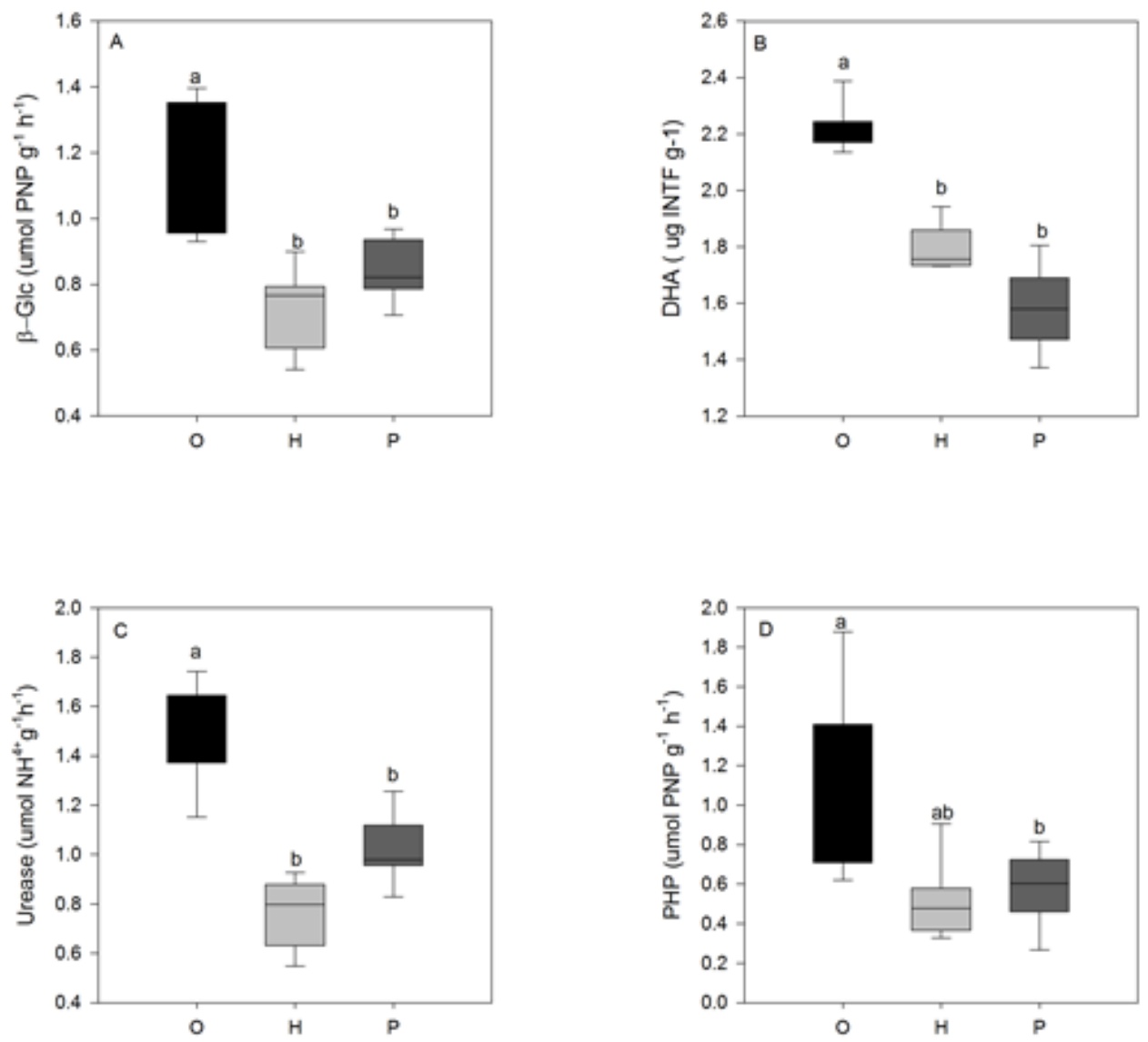

Figure 2. Mean values ( \pm standard deviation) of enzymatic activities (A) $\beta$-Glc, (B) DHA, (C) Urease and (D) PHP in soil. Different letters indicate significant differences $(P<0.05$ ) between soil management - from black (organic farming-O), light gray (herbicide-H) to dark gray (ploughing-P) - for each treatment according to one-way ANOVA. 


\subsection{PCA}

With the PCA performed on the soil physical, chemical, and biochemical properties $60 \%$ of the total variation could be explained by the first two principal components. Figure 3 shows the soil property clusters analyzed through principal components analysis, performed with the different agricultural managements studied. The first principal component (PC) explained $42 \%$ of the variation and it separates the $O$ soil samples from those of the other agricultural managements $(\mathrm{P}$ and $\mathrm{H})$. The second component explained $18 \%$ of the variance and separates the soil samples from $\mathrm{H}$ and $\mathrm{P}$ management. The first component was determined by N, SOM, Csol, AS, Veg, CEC, Ca, Cmic/C, AP, pH, K, PHP, BSR, $\mathrm{Cu}, \mathrm{EC}, \mathrm{Carb}, \mathrm{Mn}, \mathrm{Na}, \mathrm{CaCO}_{3}, \mathrm{Mg}, \mathrm{Cmic}$ and silt (correlation > 0.4). The second component was correlated with sand, extractable $\mathrm{Fe}$, $\mathrm{CaCO}_{3}, \mathrm{Mg}$, Clay, relation $\mathrm{C} / \mathrm{N}$, silt, EC, Carb, $\mathrm{Zn}$ and $\mathrm{pH}$. Figure 3 shows that the analysis has clearly clustered the soils by type of agricultural management received, and the majority of fertility and microbiological activity properties analyzed are closely associated with soils under O management.

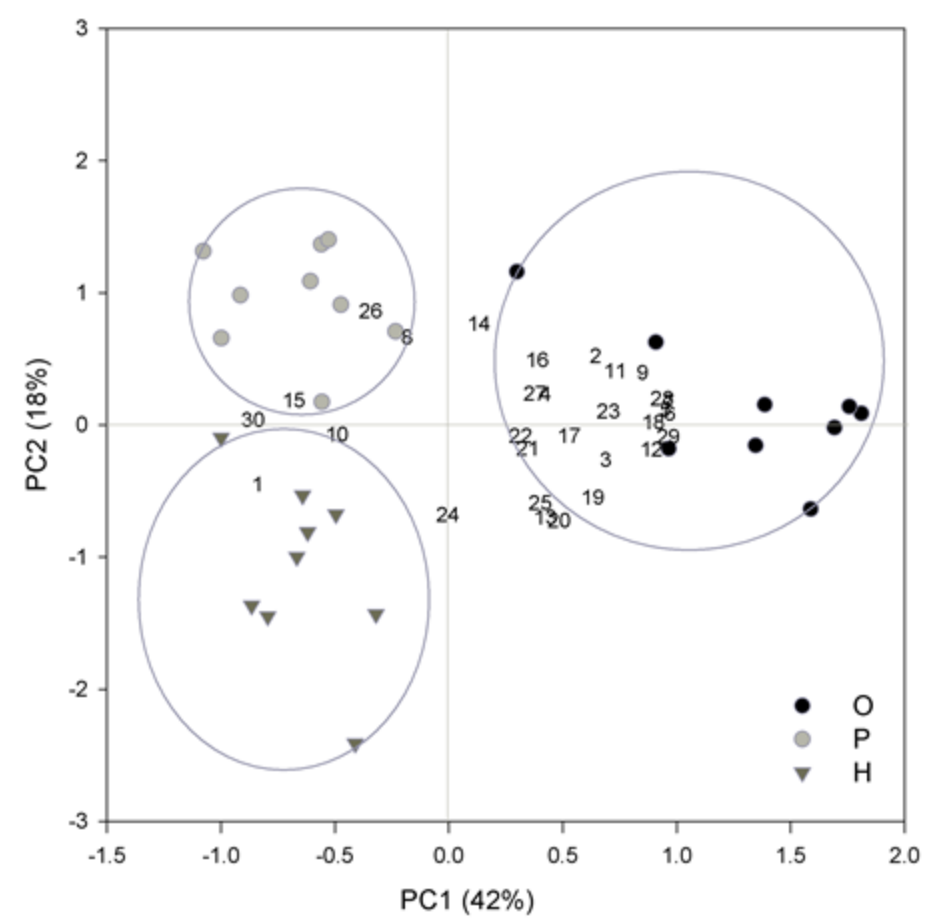

Figure 3. PCA factor scores from each agricultural management and loadings from soil properties in all management practices: Organic farming (O) (๑), Ploughing $(P)(0)$ and Herbicide $(H)(\nabla)$.

1: $\mathrm{pH} ; 2$ : EC (electrical conductivity); 3: BSR (basal soil respiration); 4: Cmic (microbial biomass carbon); 5: AS (aggregate stability); 6: $\mathrm{N}$ (total nitrogen); 7: SOM (soil organic matter); 8: CN; 9: AP (available phosphorus); 10: Na; 11: K; 12: Ca; 13: Mg; 14: Fe; 15: Cu; 16: Zn; 17: Mn; 18: CEC (cation exchange capacity); 19: Carb (calcium carbonate equivalent); 20: $\mathrm{CaCO}_{3}$ (calcium carbonate content of limestone); 21: $\beta$-Glc ( $\beta$-Glucosidase); 22: urease; 23 : PHP (acid phosphatise); 24: clay; 25: silt; 26: sand; 27: DHA (dehydrogenase); 28: Veg (vegetation cover); 29: Csol (soluble carbon); 30: Cmic/C. 


\section{Discussion}

The soil of field study is a Xerorthent, (a) Ent: young soil with little or no profile development, (b) Orthents: Entisols lacking in pedogenetic development and (c) Xerorthents: these soils have a xeric soil moisture regimen (cool and moist in winter and warm and dry in summer) (Illustrated guide to Soil Taxonomy, version 1.0, Soil Survey Staff 2014).

A combination of high throughput approaches along with physical, chemical, and microbiological methods were used to investigate three different agricultural practices in citrus orchards. This research approach provides insight into how key fertility parameters and microbiological activity respond to the different agricultural managements, how the $\mathrm{O}$ management (weeds, manure, and no chemical fertilization) improved most soil properties, and how inorganic fertilisation drastically changed soil microbial activity. These hypotheses were supported by the results obtained. First, SOM is responsible for microbiological processes and organic compound turnover. Indeed, in agricultural soils that are intensively managed, microbial activity tends to change quicker in response to organic management than community composition (Burger and Jackson 2003). Secondly, distinct enzyme activities indicated that $O$ increased the association of enzyme activity with fertility properties (Piotrowska and Wilczewski 2012; Bowles et al. 2014). Enzymatic activities may be considered as biochemical indicators of soil quality, mainly based on OM content and related biological and biochemical parameters (GarcíaRuiz et al. 2008).

In our study PHP is closely correlated with N, SOM and biological parameters such as Csol. These results are consistent with other studies that showed high correlations between different enzymatic activities and the microbial response (Acosta-Martinez et al. 2008; Bonanomi et al. 2011). The high level of enzymatic activities observed in the $\mathrm{O}$ management plot indicates that this soil is biologically and biochemically more active than the other agricultural managements. This activity in $\mathrm{O}$ treatment could be related to the higher level of SOM that also contains high levels of Csol, the Csol fraction is an important pool with respect to SOM turnover in agricultural soils, and it acts as readilyavailable substrate for soil microorganisms responsible for the enzymatic activities (GarcíaOrenes et al. 2010). The PHP activity that has been reported in the literature usually shows a negative correlation with the high presence of AP (Allison et al. 2007). In contrast, in this work we found high PHP activity in the O plot even with a high presence of AP. This behaviour could be due to the greater correlation obtained between the enzyme with Csol and SOM, suggesting that SOM and Csol have been more important than $P$ availability in regulating investment in PHP in this soil (Bowles et al. 2014). The decrease of the enzymatic activities in the $\mathrm{H}$ soil could be explained by the low levels of SOM, nutrients and also microbiological activity found. In $\mathrm{P}$ soil, this decrease is worsened by tillage management and could be modified by the potential of soil enzyme-mediated substrate catalysis (Kalender et al. 1996).

Furthermore, it was clearly observed in our survey that $\mathrm{O}$ improved the Cmic and BSR; the quantity and quality of SOM and nitrogen inputs are the overriding controls of soil microbial biomass carbon (Fierer at al. 2009; Kallenbach and Grandy 2011). Thus, different agricultural amendments (e.g. manure, leguminous cover crops, and composted materials) can stimulate Cmic differently through increases in OM (Smukler et al. 2008). In contrast, GarcíaOrenes et al. (2010) already detected low basal soil respiration quotients in agricultural soils with null inputs of $\mathrm{OM}$ under rainfed conditions in the rangelands and agriculture lands of the mountainous areas of Eastern Spain. The success of manure additions in the citrus orchards in recovering SOM, vegetation cover, and microbiological activity, must also be due to the fact that there was high soil water content as a consequence of the irrigation (Sorensen et al. 2013). The contribution of irrigation to improving soil microbial biomass has been mainly studied on soil treated with wastewater (Chaerun et al. 2011; Morugán-Coronado et al. 2011; Prado et al. 2011) and all of these studies confirm improvements as water and OM are key factors for healthy soil development (Morugán- 
Coronado et al. 2013). Soil moisture tends to have a positive influence on soil quality due to its contribution to the improvement in soil microbial activity when there are improvements in the SOM.

SOM additions from organic farming help stabilize soil from runoff losses and protect the soil surface from erosion increasing infiltration and WHC (Apezteguía et al. 2009). Moreover, the increase in SOM can lead to greater soil aggregation, which increases pore space and further promotes infiltration (Larsen et al. 2014). Additionally, SOM is the major aggregate agent and provides structure in temperate soils (Mataix-Solera et al. 2011; Gispert et al. 2013). The low SOM observed in the herbicide plot and the corresponding decrease in microbial activity affects the soil's physicochemical properties, as well as the productivity of agricultural ecosystems (De Grood et al. 2005). The aggregation of soil (AS) and SOM observed in plots $\mathrm{H}$ and $\mathrm{P}$ were lower than AS in $O$ plot, ploughing and the herbicide application facilitates decomposition of SOM due to the disruption of aggregateembedded organic matter (Tisdall and Oades 1982). Intensive tillage can be a major cause of erosion due to disruption of the soil surface and removal of protective cover that would be effective in reducing runoff and soil loss. Organic farming systems and sustainable agricultural management systems use organic inputs, leaving residue on the fields that cover at least $30 \%$ of the soil surface, and this conservation practice has been shown to reduce soil erosion and increase SOM in agricultural soils.

In comparison with conventional tillage, organic farming has potential benefits in encouraging soil structure formation, and enhancing soil microbiology such as has been shown in the Alcoleja research site. Organic farming avoids the inputs of inorganic fertilizers and their consequences, offers organic C inputs to soil, and has been used to successfully reduce soil erosion (Bilalis et al. 2003; Jordán 2004). It is also effective in preserving soil moisture and buffering severe changes in soil temperature, which can be important in Mediterranean soils to improve biological activity.

\section{Conclusions}

The main conclusion of the research carried out at Alcoleja experimental station is that in traditional citrus orchards, the organic farming strategy (manure, no tillage, high vegetation cover) contributed to better soil conditions, including high biological activity, increased enzymatic activities, more organic matter and more stable aggregates. Meanwhile, herbicide treatment and ploughing with inorganic fertilization managements resulted in low aggregate stability and low microbial biomass.

The implication of this work potentially entails environmentally positive applications in soil agricultural management (soil protection, residue crop reuse and halting soil degradation). Hence, the present research represents a further step towards a more sustainable crop production in Mediterranean agricultural soil.

\section{Acknowledgements}

Eric Brevik kindly reviewed and improved the original manuscript. The research projects GL2008-02879/BTE, LEDDRA 243857 and RECARE supported this research. The authors acknowledge Frances Young for improving the English. 


\section{REFERENCES}

- Acosta-Martínez V, Acosta-Mercado D, SomajorRamírez D, Cruz-Rodríguez L. 2008. Microbial community and enzymatic activities under different management in semiarid soils. Appl Soil Ecol. 38:249-260.

- Alexakis D. 2011. Diagnosis of stream sediment quality and assessment of toxic element contamination sources in East Attica, Greece. Environ Earth Sci. 63:1369-1383.

- Allison VJ, Condron LM, Peltzer DA, Richardson SJ, Turner BI. 2007. Changes in enzyme activities and soil microbial community composition along carbon and nutrient gradients at the Franz Josef chronosequence, New Zeland. Soil Biol Biochem. 39:1770-1781.

- Apezteguía HP, Izaurralde RC, Sereno R. 2009. Simulation study of soil organic matter dynamics as affected by land use and agricultural practices in semiarid Cordoba, Argentina. Soil Till Res. 102(1):101-108.

- Balota EL, Yada IF, Amaral H, Nakatani AS, Dick RP, Coyne MS. 2013. Long-term land use influences soil microbial biomass $p$ and $s$, phosphatase and arylsulfatase activities, and mineralization in a brazilian oxisol. Land Degrad Dev. 25:397-406.

- Bilalis D, Sidiras N, Economou G, Vakali C. 2003. Effect of different levels of wheat straw soil surface coverage on weed flora in Vicia faba crops. J Agron Crop Sci. 189:223-241.

- Blagodatskaya E, Yuyukina T, Blagodatsky S, Kuzyakov Y. 2011. Turnover of soil organic matter and of microbial biomass under $\mathrm{C} 3-\mathrm{C} 4$ vegetation change: Consideration of ${ }^{13} \mathrm{C}$ fractionation and preferential substrate utilization. Soil Biol Biochem. 43(1):159-166.

- Bonanomi G, D'Ascoli R, Antignani V, Capodilupo M, Cozzolino L, Marzaioli R, Puopolo G, Rutigliano FA, Scelza R, Scotti R. 2011. Assessing soil quality under intensive cultivation and tree orchards in Southern Italy. Appl Soil Ecol. 47:184-194.

- Bowles TM, Acosta-Martínez V, Calderón F, Jackson LE. 2014. Soil enzyme activities, microbial communities, and carbon and nitrogen availability in organic agroecosystems across an intensively-managed agricultural landscape. Soil Biol Biochem. 68:252-262.

- Bremmer JM, Mulvaney CS. 1982. Nitrogen total. In: Page AL, Miller RH, Keeney DR, editors. Methods of Soil Analysis. Part 2. Chemical and Microbiological Properties. Madison: ASA. p. 595-624.

- Burger M, Jackson LE. 2003. Microbial immobilization of ammonium and nitrate in relation to ammonification and nitrification rates in organic and conventional cropping systems. Soil Biol Biochem. 35:29-36.

- Caravaca F, Masciandaro G, Ceccanti B. 2002. Land use in relation to soil chemical and biochemical properties in a semiarid Mediterranean environment. Soil Till Res. 68:23-30.
- Cerdà A, Hooke J, Romero-Díaz A, Montanarella L, Lavee H. 2010. Soil Erosion on Mediterranean Type Ecosystems. Land Degrad Dev. 21:71-217.

- Cerdà A, Imeson AC, Poesen J. 2007. Soil Water Erosion in Rural Areas. Catena 71:191-252.

- Chaerun SK, Pangesti NP, Toyota K, Whitman WB. 2011. Changes in microbial functional diversity and activity in paddy soils irrigated with industrial wastewaters in Bandung West Java Province, Indonesia. Water Air Soil Poll. 217(1-4):491-502.

- De Grood SH, Classens VP, Scow KM. 2005. Microbial community composition on native and drastically disturbed serpentine soils. Soil Biol Biochem. 37:1427-1435.

- Díez JA. 1982. Consideraciones sobre la utilización de la técnica extractiva de Burriel-Hernando para la evaluación de fósforo asimilable en suelos. Anales de Edafología y Agrobiología 41:1345-1353.

- Fierer N, Strickland MS, Liptzin D, Bradford MA, Cleveland CC. 2009. Global patterns in belowground communities. Ecol Lett. 12:1238-1249.

- Forster JC. 1995. Soil physical analysis. In: Alef K, Nannipieri P, editors. Methods in Applied Soil Microbiology and Biochemistry. San Diego, CA: Academic Press Inc.

- García C, Hernández MT, Costa F. 1997. Potential use of dehydrogenase activity as an index of microbial activity in degraded soils. Commun Soil Sci Plant Nutr. 28:123-134.

- García-Orenes F, Guerrero C, Roldán A, Mataix-Solera J, Cerdà A, Campoy M, Zornoza R, Bárcenas G, Caravaca F. 2010. Soil microbial biomass and activity under different agricultural management systems in a semiarid Mediterranean agroecosystem. Soil Till Res. 109(2):110-115.

- García-Orenes F, Morugán-Coronado A, Zornoza R, Scow K. 2013. Changes in Soil Microbial Community Structure Influenced by Agricultural Management Practices in a Mediterranean Agro-Ecosystem. PLoS ONE 8:e80522.

- García-Ruiz R, Ochoa V, Hinojosa B, Carreira, JA. 2008. Sustainability of enzyme activities of the monitoring of soil quality improvement in organic agricultural systems. Soil Biol Biochem. 40:2137-2135.

- Gispert M, Emran M, Pardini G, Doni S, Ceccanti B. 2013. The impact of land management and abandonment on soil enzymatic activity, glomalin and aggregate stability. Geoderma 202-203:51-61.

- Imfeld G, Vuilleumier S. 2012. Measuring the effects of pesticides on bacterial communities in soil: a critical review. Eur J Soil Biol. 49:22-30.

- Jenkinson DS, Powlson DS. 1976. The effects of biocidal treatments on metabolism in soil-I. Fumigation with chloroform. Soil Biol Biochem. 8:209-213.

- Jordán CF. 2004. Organic farming and agroforestry: Alley cropping for mulch production for organic farms of southeastern United States. Agroforestry Systems 61-62:79-90. 
- Kalender E, Kampichler C, Horak O. 1996. Influence of heavy metals on the functional diversity of soil microbial communities. Biol Fertil Soils 23:299-306.

- Kallenbach C, Grandy AS. 2011. Controls over soil microbial biomass responses to carbon amendments in agricultural systems: a meta-analysis. Agric Ecosyst Environ. 144:241-252.

- Knudsen D, Peterson GA, Pratt PF. 1982. Lithium, sodium and potassium. Methods of soil analysis, 2. Madison, WI: ASA-SSSA. p. 225-246.

- Lampkin NH, Measures M, Padel S, editors. 2011. Organic Farm Management Handbook. 9th ed. Newbury: Organic Research Centre.

- Larsen E, Grossman J, Edgell J, Hoyt G, Osmond D, Hu S. 2014. Soil Biological properties, soil losses and corn yield in long-term organic and conventional farming systems. Soil Till Res. 139:37-45.

- Macci C, Doni S, Peruzzi E, Mennone C, Masciandaro G. 2013. Biostimulation of soil microbial activity through organic fertilizer and almond tree association. Land Degrad. Dev. doi: 10.1002/ldr.2234.

- Mataix-Solera J, García-Irles L, Morugán A, Doerr SH, García-Orenes F, Arcenegui V, Atanassova I. 2011. Soil water repellency patterns of a former wastewater disposal field with calcareous soil and effects of remediation approaches. Geoderma 165:78-83.

- Morugán-Coronado A, Arcenegui V, García-Orenes F, Mataix-Solera J, Mataix-Beneyto J. 2013. Application of soil quality indices to assess the status of agricultural soils irrigated with treated wastewaters. Solid Earth 4:119-127.

- Morugán-Coronado A, García-Orenes F, Mataix-Solera J, Arcenegui V, Mataix-Beneyto J. 2011. Short-term effects of treated wastewater irrigation on Mediterranean calcareous soil. Soil Till Res. 112(1):18-26.

- Pampulha ME, Oliveira A. 2006. Impact of an herbicide combination of bromoxynil and prosulfuron on soil microorganisms. Curr Microbiol. 53:238-243.

- Piotrowska A, Wilczewski E. 2012. Effects of catch crops cultivated for green manure and mineral nitrogen fertilization on soil enzyme activities and chemical properties. Geoderma 189-190:72-80.

-Porta J, López-Acevedo M, Rodríguez R. 1986. Técnicas y experimentos en edafología. Barcelona, Spain: Col•legi Oficial d'Enginyers Agrònoms de Catalunya.

- Prado AG, Evangelista SM, SouzaDe JR, Matos JG, Souza MA, Oliveira DA, Airoldi C. 2011. Effect of the irrigation with residual wastewaters on microbial soil activity of the ornamental flowers (Dahlia pinnata) cultures monitored by isothermal calorimetry. $\mathrm{J}$ Therm Anal Calorim. 106(2):431-436.

- Reganold JP, Andrews PK, Reeve JR, Carpenter-Boogs L, Schadt CW, Alldredge R, Ross CF, Davies NM, Zhou J. 2010. Fruit and soil quality of organic and conventional strawberry agroecosystem. PLoS ONE 5(9):e12346.
- Roig A, Romero M, Lax A, Fernández FG. 1980. Estudio comparativo de métodos de determinación de capacidad de cambio catiónica en suelos calizos. An Edafol Agrobiol. 39:2021-2032.

- Roldán A, Caravaca F, Hernández MT, García-Izquierdo C, Sánchez-Brito C, Velásquez M, Tiscareño M. 2003. Notillage, crop residue additions, and legume cover cropping effects on soil quality characteristics under maize in Patzcuaro watershed (Mexico). Soil Till Res. 72:65-73.

- Roldán A, García-Orenes F, Lax A. 1994. An incubation experiment to determinate factors involving aggregation changes in an arid soil receiving urban refuse. Soil Biol Biochem. 26:1699-1707.

- Smukler SM, Jackson LE, Murphree L, Yokota R, Koike ST, Smith RF. 2008. Transition to large-scale organic vegetable production in the Salinas Valley, California. Agric Ecosyst Environ. 126:168-188.

- Sofo A, Scopa A, Dumontet S, Mazzatura A, Pasquale V. 2012. Toxic effects of four sulphonylureas herbicides on soil microbial biomass. J Environ Sci Health 47(7):653-659.

- Soil Survey Staff. 2010. Keys to Soil Taxonomy. $11^{\text {th }}$ ed. Washington DC, USA: USDA-NRCS. p. 106-111.

- Soil Survey Staff. 2014. Keys to Soil Taxonomy. $12^{\text {th }}$ ed. Washington, DC, USA: USDA-NRCS.

- Sorensen PO, Germino MJ, Feris KP. 2013. Microbial community responses to 17 years of altered precipitation are seasonally dependent and coupled to co-varying effects of water content on vegetation and soil C. Soil Biol Biochem. 64:155-163.

- Tabatabai MA. 1994. Enzymes. In: Weaver RW, Angle JS, Bottomley PS, editors. Methods of Soil Analysis. Part 2. Madison, WI: Soil Science Society of America Journal. p. $755-833$.

- Tisdall JM, Oades JM. 1982. Organic matter and waterstable aggregates in soils. Soil Sci Soc Am J. 33(2):141-163.

- Vance ED, Brookes PC, Jenkinson DS. 1987. An extraction method for measuring soil microbial biomass C. Soil Biol Biochem. 19:703-707.

- Walkley A, Black IA. 1934. An examination of the Degtjareff method for determining soil organic matter and a proposed modification of the chromic acid titration method. Soil Sci. 37:29-38.

- Zelles L. 1999. Fatty acid patterns of phospholipids and lipopolysaccharides in the characterization of microbial communities in soil: a review. Biol. Fertil Soils 29:111-129.

- Zornoza R, Guerrero C, Mataix-Solera J, Scow KM, Arcenegui V, Mataix-Beneyto J. 2009. Changes in soil microbial community structure following the abandonment of agricultural terraces in mountainous areas of Eastern Spain. Appl Soil Ecol. 42:315-323.

- Zornoza R, Mataix-Solera J, Guerrero C, Arcenegui V, Mayoral AM. 2007. Soil properties under natural forest in the Alicante Province of Spain. Geoderma 142:334-341. 